Keywords: Double-positive T-lymphocytes, Flow cytometry, Natural killer T-cells

Anahtar Sözcükler: Çift pozitif T-lenfositleri, Akış sitometrisi, Doğal öldürücü T-hücreleri

Informed Consent: Not applicable.

\section{Authorship Contributions}

Concept: M.S.G., J.M.G.; Analysis or Interpretation: M.S.G., J.M.G.; Literature Search: M.S.G., J.M.G.; Writing: M.S.G., J.M.G.

Conflict of Interest: The authors declare no conflict of interest.

Financial Disclosure: The authors declared that this study received no financial support.

\section{References}

1. Gonzalez-Mancera MS, Bolaños NI, Salamanca M, Orjuela GA, Rodriguez AN, Gonzalez JM. Percentages of CD4+CD8+ double-positive T lymphocytes in the peripheral blood of adults from a blood bank in Bogotá, Colombia. Turk J Hematol 2020;37:36-41.

2. Krovi SH, Gapin L. Invariant natural killer T cell subsets-more than just developmental intermediates. Front Immunol 2018;9:1393.

3. Zloza A, Al-Harthi L. Multiple populations of $\mathrm{T}$ lymphocytes are distinguished by the level of CD4 and CD8 coexpression and require individual consideration. J Leukoc Biol 2006;79:4-6.

4. Kelly-Rogers J, Madrigal-Estebas L, O'Connor T, Doherty DG. Activationinduced expression of CD56 by $T$ cells is associated with a reprogramming of cytolytic activity and cytokine secretion profile in vitro. Hum Immunol 2006;67:863-873.

5. Van Acker HH, Capsomidis A, Smits EL, Van Tendeloo VF. CD56 in the immune system: More than a marker for cytotoxicity? Front Immunol 2017;8:892.

- Copyright 2020 by Turkish Society of Hematology

Turkish Journal of Hematology, Published by Galenos Publishing House

\title{
Vaccination and Thrombotic Thrombocytopenic Purpura
}

\author{
Așılama ve Trombotik Trombositopenik Purpura
}

(Di) Irfan Yavaşoğlu

Adnan Menderes University Faculty of Medicine, Division of Hematology, Aydın, Turkey

To the Editor,

The article entitled "Diagnostic Testing for Differential Diagnosis in Thrombotic Microangiopathies," written by Zini and De Cristofaro [1] and published in one of the recent issues of your journal, was quite interesting. Herein, I wish to contribute to that article.

In the adult age group, vaccines did not contribute to the development of immune thrombocytopenia (ITP), but an increase was reported in diphtheria-tetanus-pertussis-poliomyelitis vaccines without statistical significance [2]. Immune-origin thrombocytopenia may be developed after many vaccines such as measles-mumps-rubella and varicella, polio, rabies, and meningococcal $C$, especially in childhood. This occurs with $1-3 / 100,000$ vaccine doses. Molecular mimicry theory is thought to play a role in the development of ITP [3]. In adult cases, development of thrombocytopenic thrombotic purpura (TTP) has been reported with some vaccines $[4,5,6,7,8,9]$. These cases

\begin{tabular}{|l|l|l|l|l|l|}
\hline \multicolumn{2}{|l|}{ Table 1. TTP cases developed after vaccination in the literature. } \\
\hline Vaccine type & $\mathbf{n}$ & Age (years) & Sex & Time of development & Literature \\
\hline Rabies & 1 & 28 & Male & $14^{\text {th }}$ day & Kadikoylu et al. [4] \\
\hline Pneumococcal & 1 & 68 & Female & $15^{\text {th }}$ day & Kojima et al. [5] \\
\hline Influenza & 1 & Unknown & Unknown & Unknown & Ramakrishnan and Parker [6] \\
\hline Influenza & 1 & 54 & Male & $5^{\text {th }}$ day & Dias and Gopal [7] \\
\hline H1N1 & 1 & 56 & Male & $13^{\text {th }}$ day & Hermann et al. [8] \\
\hline Influenza & 1 & 23 & Female & $14^{\text {th }}$ day & Brown et al. [9] \\
\hline
\end{tabular}


are summarized in Table 1. It is generally seen with vaccinations against viral agents. $A$ frequent occurrence with vaccines against influenza may be relative due to more intensive vaccination. It is especially important within 2 weeks after vaccination.

Consequently, attention should be paid to the development of TTP after vaccination.

Keywords: Vaccination, Thrombotic thrombocytopenic purpura

Anahtar Sözcükler: Aşılama, Trombotik trombositopenik purpura

Financial Disclosure: The author declared that this study received no financial support.

\section{References}

1. Zini G, De Cristofaro R. Diagnostic testing for differential diagnosis in thrombotic microangiopathies. Turk J Hematol 2019;36:222-229.

2. Grimaldi-Bensouda $L$, Michel $M$, Aubrun $E$, Leighton $P$, Viallard JF, Adoue D, Magy-Bertrand N, Tisserand G, Khellaf M, Durand JM, Quittet P, Fain O, Bonnotte B, Morin AS, Limal N, Costedoat-Chalumeau N, Morel N, PanPetesch B, Decaux O, Mahevas M, Ruel M, Sacre K, Lefrere F, Abenhaim L, Godeau B; PGRx Immune Thrombocytopenia Study Group. A case-control study to assess the risk of immune thrombocytopenia associated with vaccines. Blood 2012;120:4938-4944.

3. Cecinati V, Principi N, Brescia L, Giordano P, Esposito S. Vaccine administration and the development of immune thrombocytopenic purpura in children. Hum Vaccin Immunother 2013;9:1158-1162.
4. Kadikoylu G, Yavasoglu I, Bolaman Z. Rabies vaccine-associated thrombotic thrombocytopenic purpura. Transfus Med 2014;24:428-429.

5. Kojima $Y$, Ohashi $H$, Nakamura T, Nakamura $H$, Yamamoto $H$, Miyata $Y$, lida $H$, Nagai $\mathrm{H}$. Acute thrombotic thrombocytopenic purpura after pneumococcal vaccination. Blood Coagul Fibrinolysis 2014;25:512-514.

6. Ramakrishnan N, Parker LP. Thrombotic thrombocytopenic purpura following influenza vaccination--a brief case report. Conn Med 1998;62:587-588.

7. Dias PJ, Gopal S. Refractory thrombotic thrombocytopenic purpura following influenza vaccination. Anaesthesia 2009;64:444-446.

8. Hermann R, Pfeil A, Busch M, Kettner C, Kretzschmar D, Hansch A, La Rosée $\mathrm{P}$, Wolf G. Very severe thrombotic thrombocytopenic purpura (TTP) after H1N1 vaccination. Med Klin (Munich) 2010;105:663-668.

9. Brown RC, Blecher TE, French EA, Toghill PJ. Thrombotic thrombocytopenic purpura after influenza vaccination. Br Med J 1973;2:303.

\section{Reply}

To the Editor,

Thank you for your communication.

The short letter that refers to our article provides some useful additional information and does not need any reply or comment.

Best regards,

Gina Zini and Raimondo De Cristofaro

๑Copyright 2020 by Turkish Society of Hematology

Turkish Journal of Hematology, Published by Galenos Publishing House

Address for Correspondence/Yazışma Adresi: İrfan Yavaşoğlu, M.D., Adnan Menderes University Faculty of Medicine, Division ofs Hematology, Aydın, Turkey

Phone : +902562120020

E-mail : dr_yavas@yahoo.com ORCID: orcid.org/0000-0003-1703-2175
Received/Geliş tarihi: February 12, 2020

Accepted/Kabul tarihi: March 31, 2020 